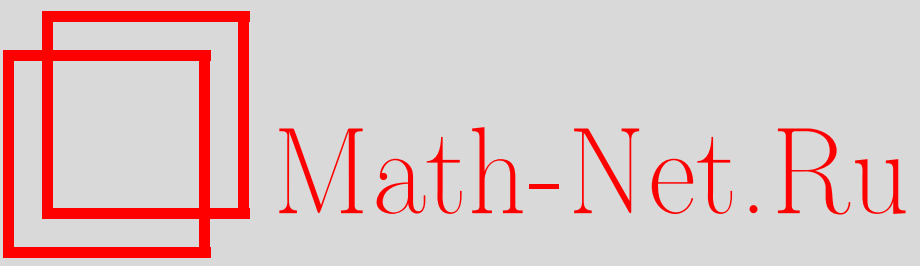

Э. Б. Винберг, Е. С. Голод, Е. И. Зельманов, В. А. Исковских, В. Н. Латышев, Ю. И. Манин, А. В. Михалёв, А. Н. Паршин, И. Р. Шафаревич, Алексей Иванович Кострикин (некролог), УМН, 2001, том 56, выпуск 3, 143-145

DOI: https://doi.org/10.4213/rm395

Использование Общероссийского математического портала Math-Net.Ru подразумевает, что вы прочитали и согласны с пользовательским соглашением http: //www . mathnet.ru/rus/agreement

Параметры загрузки:

IP: 54.80 .73 .141

26 апреля 2023 г., 08:19:51 


\section{АЛЕКСЕЙ ИВАНОВИЧ КОСТРИКИН}

22 сентября 2000 года после тяжелой и продолжительной болезни скончался Алексей Иванович Кострикин.

А. И. Кострикин родился 12 февраля 1929 года в селе Большой Морец Еланского района Волгоградской области. Именно в этот год известный алгебраист и ученьй-энциклопедист О.Ю. Шмидт организовал кафедру высшей алгебры в Московском университете. В своей крестьянской семье А. И. Кострикин был последним, десятым ребенком. Замечательные сельские учителя привили ему любовь к учебе и занятиям математикой.

В 1947 году А. И. Кострикин поступил в Саратовский государственньй университет. В 1951 году, как один из лучших студентов Саратовского университета, он был переведен на механико-математический факультет Московского государственного университе-

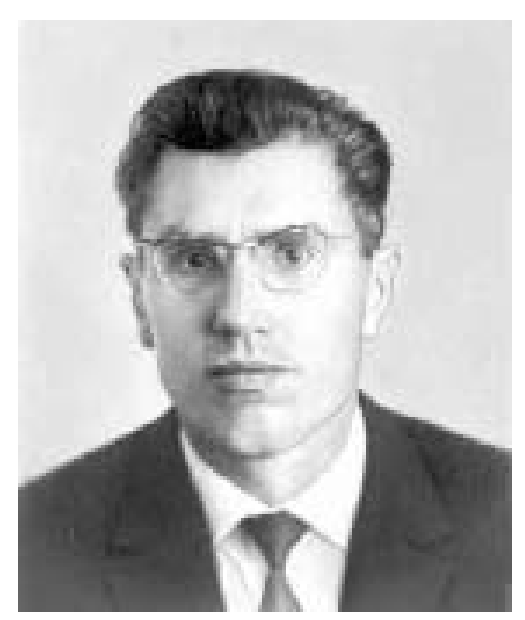
та, которьй окончил в 1952 году. Тема его дипломной работы "Конечные $p$-группы и кольца Ли" была предложена молодым профессором И.Р. Шафаревичем, под руководством которого А. И. Кострикин продолжил обучение в аспирантуре Математического института им. В. А. Стеклова АН СССР. Верным сотрудником МИАН Алексей Иванович оставался всю свою жизнь.

В 1963 году А.И. Кострикин начал свою преподавательскую деятельность в МГУ им. М.В. Ломоносова на кафедре высшей алгебре. В 1972 году он возглавил кафедру высшей алгебры и руководил ею в течение 28 лет, достойно продолжив традиции предшественников - О.Ю. Шмидта и А.Г. Куроша. Его доброжелательность, интеллигентность и скромность, объективность и принципиальность снискали уважение и любовь коллег и учеников. На мех-мате раскрылось дарование А. И. Кострикина как замечательного педагога и наставника молодежи. Он был прекрасньм лектором. Прочитанные им основные алгебраические курсы и спецкурсы привлекали многих способных учеников. А.И. Кострикин подготовил более 30 кандидатов физико-математических наук. Впоследствии шесть из них защитили докторские диссертации (С. П. Струнков, Ю. В. Кузьмин, М.И. Кузнецов, А. С. Джумадильдаев, С.М. Скрябин, Фам Хыу Тьеп). Работу с аспирантами Алексей Иванович продолжал, несмотря на болезнь, до последних дней своей жизни.

Теплые и дружеские отношения со многими учениками сохранялись на всю жизнь. С некоторыми из них долгое время продолжалась совместная научная деятельность. В конце 70-х годов Алексей Иванович становится деканом механико-математического факультета МГУ.

Плодотворная педагогическая работа А.И. Кострикина привела в 1977 году к изданию его широко известного учебника для студентов университетов. Этот учебник был переведен на мно- 
гие язьки. Впоследствии совместно с Ю.И. Маниным были опубликованы учебное пособие на эту тему и совместно с сотрудниками кафедры высшей алгебры сборник задач. Итогом педагогической деятельности А. И. Кострикина стало создание учебника в трех частях, соответствующих трем семестрам университетского курса алгебры. Этот учебник, практически заново написанный, издан в 2000 году.

Основной проблемой, интересовавшей А. И. Кострикина в 50-е годы, была ослабленная проблема Бернсайда для простой экспоненты. Гипотеза состояла в том, что существует наибольшая конечная группа $\overline{B(d, p)}$ с $d>1$ порождающими и с тождеством $x^{p}=1$. Любая другая конечная группа с этими условиями является факторгруппой группы $\overline{B(d, p)}$. Согласно подходу Цассенхауза-Магнуса эта проблема может быть сформулирована в следующем виде. Кольцо Ли $L(d, p)$ над простым полем $\mathbb{F}_{p}$ c $d$ порождающими и с тождеством $\mathrm{ad} x^{p-1} y=0$ (условие Энгеля) является нильпотентным. В 1952 году (год окончания Московского университета) А. И. Кострикин смог доказать нильпотеность кольца $L(2,5)$. В 1954 году, являясь аспирантом И.Р. Шафаревича в Математическом институте им. В.А. Стеклова, он установил неравенство $|\overline{B(d, 5)}| \leqslant 5^{34}$. В своей кандидатской диссертации (1956 г.) А. И. Кострикин ввел локально нильпотентньй радикал в энгелевых алгебрах Ли и почти без вычислений доказал существование группы $\overline{B(d, p)}$ при $d>1$ и $p=5$ или $p=7$. В диссертации был развит метод сәндв ичей. Элемент $c \neq 0$ алгебры Ли $L$ назьвается сэндвичем, если выполнены тождества

$$
\operatorname{ad}(c)^{2}=0 \quad \text { и } \operatorname{ad}(c) \operatorname{ad}(x) \operatorname{ad}(c)=0
$$

для любого $x \in L$. Развитие метода сэндвичей привело А.И. Кострикина в 1958 году к положительному решению ослабленной проблемы Бернсайда для любого простого числа $p$. Подробное изложение решения проблемы дано в его монографии "Вокруг Бернсайда" (1986 г.).

Спустя 30 лет в 1989 году, применяя модифицированньй метод сэндвичей и развивая другие интересные идеи, Е.И. Зельманов решил ослабленную проблему Бернсайда для произвольного показателя. Дальнейшие улучшения принадлежат М. Воен-Ли.

Метод сэндвичей нашел приложение в классификации простых конечномерных алгебр Ли над полем характеристики $p>5$. Другим источником этой классификации является изучение бесконечномерных алгебр Ли картановского типа. Их аналоги в конечной характеристике были введены в совместной с И.Р. Шафаревичем заметке 1966 года. Авторами было замечено, что все известные в то время неклассические простые $p$-алгебры Ли содержатся (при $p>5$ ) в четыpex бесконечных сериях (общей, специальной, гамильтоновой и контактной), которые возникают из классификации бесконечномерных псевдогрупп преобразований, разработанной Э. Картаном. В рамках этой и последующей обширной работы 1969 года была высказана основная гипотеза, описывающая все простые $p$-алгебры Ли в характеристике $p>5$. Эта гипотеза на долгие годы определила направление исследований в этом разделе алгебры и в конце концов была доказана Блоком и Вильсоном.

Изучение целого ряда важных и интересных проблем в алгебре, связанных с изложенными вьше, было также начато А. И. Кострикиным. Например, классификация конечномерных неассоциативных алгебр, группа автоморфизмов которых действует транзитивно на всех ненулевых элементах. Другая проблема - вычисление числа унитарных консервативных комплексных многочленов и нахождение верхней границы в терминах $p$ для класса нильпотентности кольца Ли, допускающего автоморфизм простого порядка $p$ без неподвижных точек.

В 90-х годах Алексей Иванович заинтересовался ортогональными разложениями классических простых алгебр Ли в прямую сумму своих картановских подалгебр. В дальнейшем это привело к изучению в простых алгебрах Ли целочисленных решеток, инвариантных относительно формы Киллинга. Неожиданно оказалось, что эти задачи приводят к построению содержательной теории, имеющей применения и вне теории алгебр Ли. Например, инвариантные решетки можно использовать для получения естественных представлений некоторых простых конечных групп. Результаты плодотворных исследований, проведенных совместно со многими молодыми математиками, подытожены в монографии “Ортогональные разложения и целочисленные решетки” (1994 г., на англ. яз., совм. с Фам Хыу Тьеп). 
Более подробной обзор резултатов А. И. Кострикина и список его публикаций приведены в специальном выпуске "Journal of Mathematical Sciences" (1999 г.), посвященном 70-летию со дня рождения Алексея Ивановича.

Научные достижения А. И. Кострикина были высоко оценены математической общественностью. Он получил Государственную премию СССР в 1968 году, был избран членом-корреспондентом АН СССР в 1976 году, удостоен премии Ломоносова в 1997 году. В 1998 году ему было присвоено звание заслуженного профессора МГУ. Он был приглашенным докладчиком на международных конгрессах математиков в Стокгольме (1962 г.) и Нице (1970 г.) и на многих международных алгебраичесих конференциях. А.И. Кострикин был членом редакции журналов "Communications in Algebra" со дня его основания, "Математический сборник", "Вестник Московского университета" (сер. матем., мех.), "Algebra Colloquium".

А. И. Кострикин всегда был добрьм и интересным человеком, открытым для общения. Он был прекрасным организатором, и его работа на механико-математическом факултете МГУ и в редакциях журналов помогала поддерживать высокий уровень научных исследований. С редкостным мужеством Алексей Иванович выполнял свои многочисленные обязанности в годы тяжелой болезни.

Друзья, ученики и коллеги Алексея Ивановича сохранят в своей памяти его светльй образ.

Э. Б. Винберг, Е. С. Голод, Е. И. Зельманов, В. А. Исковских, В. Н. Латыиев, Ю. И. Манин, А. В. Михалев, А. Н. Паршин, И. Р. Шафаревич, А. Л. Шмелькин 